\title{
INCIDENCE OF ABO AND RH D BLOOD GROUP AMONG THE PEOPLE ATTENDING IN TRANSFUSION MEDICINE DEPARTMENT OF DHAKA MEDICAL COLLEGE HOSPITAL
}

\author{
CHOWDHURY FS ${ }^{1}$, BEGUM HA ${ }^{2}$, BEGUM HA ${ }^{3}$, NASREEN $Z^{4}$, SIDDIQUI MAE ${ }^{5}$, HOQUE MM ${ }^{6}$, \\ ISLAM K ${ }^{7}, \mathrm{ABBASI} \mathrm{AA}^{8}, \mathrm{DEB} \mathrm{SR}^{9}$
}

\begin{abstract}
:
Introduction: Among 30 blood groups $A B O$ and Rh are major blood groups.

Objective: The study was carried out to find out the incidence of $A B O$ and Rh $d$ blood group among the people attending in transfusion medicine department of Dhaka medical college hospital.

Methods: This study was carried out in transfusion medicine department of Dhaka medical college hospital between January and December 2010. Total 31941 people of O days to 100 years of both sexes were included in this study. After collecting $5 \mathrm{ml}$ blood ABO grouping was done by forward and reverse method and Rh typing was done by using two commercial anti $D$ and ICT.

Results: Among them blood group A were 8077(25.24\%), B were 10434(32.66\%), O were $10705(33.51 \%)$ and $A B$ were $2725(8.33 \%)$. Rh D positive were 30809(96.41\%) and $\mathrm{Rh} D$ negative were 1132(3.54\%).
\end{abstract}

Key words: $A B O$ blood group, Rh type.

J Dhaka Med Coll. 2012; 21(1) : 37-40.

\section{Introduction:}

Karl Landsteiner discovered the ABO blood group in $1901^{1}$.Karl Landsteiner and Weber discovered $\mathrm{Rh}$ blood group in $1940^{2}$. Classification of blood based on the presence of inherited antigenic structure on the red blood cell surface and some body fluids. Several of these antigens can stem from one allele (or very closely linked genes) and collectively form a blood group system ${ }^{3}$. Blood types are inherited and represent contributions from both parents. Total of 30 human blood group systems are recognized by International Society of Blood Transfusion ${ }^{4}$. Over 600 different blood group antigens have been found ${ }^{5}$. Many of them are rare. Some was being found mainly in certain ethnic group. An individual have same blood group for life. But very rarely an individuals blood group changes through addition or suppression of an antigen in infection, malignancy or autoimmune diseases or after liver transplantation, bone marrow transplantation $6,7,8$. Some blood types are associated with inheritance of other disease i.e., Kell antigen is sometimes with McLeod syndrome ${ }^{9}$.Certain blood types may affect susceptibility to infection i.e. ,Duffy antigen resistant to plasmodium $\operatorname{vivax}^{10}$. The ABO system is the most important blood group system in human. Antigen A and B present in

1. Dr. Fahmida Sharmin Chowdhury, Assistant Registrar, Department of Transfusion Medicine, DMCH, Dhaka.

2. Dr. Hosne Ara Begum, Associate Professsor, Department of Transfusion Medicine, DMCH, Dhaka.

3. Dr. Husne Ara Begum, Professor, Department of Transfusion Medicine, DMCH, Dhaka.

4. Dr. Zubaida Nasrin, Medical Officer, Department of Transfusion Medicine, DMCH, Dhaka.

5. Dr. Md. Ali Ehsan Siddiqui, Consultant, Department of Cardiology, NITOR, Dhaka.

6. Dr. Md. Mazharul Hoque, Assistant Professor, Department of Transfusion Medicine, DMCH, Dhaka.

7. Dr. Kashfia Islam, Medical Officer, Department of Transfusion Medicine, DMCH, Dhaka.

8. Dr. Asma Akhter Abbasi, Honorary Medical Officer, Department of Transfusion Medicine, DMCH, Dhaka.

9. Dr. Sudip Ranjan Deb, RP, DMCH, Dhaka

Correspondence : Dr. Fahmida Sharmin Chowdhury, Assistant Registrar, Department of Transfusion Medicine, $\mathrm{DMCH}$, Dhaka. 
all tissue and body fluid except CNS besides red cell ${ }^{11}$. Anti $\mathrm{A}$ and anti $\mathrm{B}$ antibodies are usually IgM produced in the first year of life by sensitization to environmental substances like food, bacteria, virus. The Rh system is the second most significant blood group system. There are $50 \mathrm{Rh}$ antigens. The most important is $\mathrm{D}$ antigen because it is most likely to provoke an immune response. It is common for D negative individuals. Commonly used term $\mathrm{Rh}$ positive and $\mathrm{Rh}$ negative refers to $\mathrm{D}$ antigen only .D negative individuals can produce IgG Anti D following sensitization -fetomaternal transfusion of blood from a fetus in pregnancy or occasionally transfusion of $\mathrm{D}$ positive blood 12. Before blood transfusion compatibility test must be done. If a unit of incompatible blood is transfused a severe acute haemolytic transfusion reaction with haemolysis renal failure, shock is likely to occur and death may occur. Patient should received their own blood or type specific blood to minimize the chance of transfusion reaction. A pregnant woman can make IgG antibodies if her fetus has a blood group antigen that she does not have.

\section{Methodology:}

IN between January 2010 and December 2010 total 31941 people of 0 day to 100 years of both sexes were included in this study. From each individual $5 \mathrm{ml}$ of venous blood was drawn by sterile syringe and was collected in a sterile test tube. Serum and cell was separated by centrifugation. After washing four times $10 \%$ cell suspension was made. ABO grouping was done by forward and reverse method but in new born only forward grouping was done. Rh typing was done by using two commercial anti D and ICT.

Laboratory method for determination of $\mathrm{ABO}$ blood group

\begin{tabular}{lcccccc}
\hline Anti B & Anti A & Anti AB & A Cell & B Cell & O Cell & Interpretation \\
\hline- & + & + & - & + & - & A Group \\
+ & - & + & + & - & - & B Group \\
+ & + & + & - & - & - & AB Group \\
- & - & - & + & + & - & O Group \\
- & - & - & + & + & + & Bombay Group \\
\hline
\end{tabular}

Laboratory method for determination of $\mathrm{Rh} \mathrm{D}$ blood group

\begin{tabular}{lccc}
\hline Anti D & Anti D & AB serum & Interpretation \\
+ & + & - & Rh D positive \\
- & - & - & Rh D negative \\
+ & + & + & ICT \\
+ & - & - & Repeat test \\
\hline
\end{tabular}

\section{Results:}

Table-I

Frequency of $A B O$ blood group ( $n=31941)$

\begin{tabular}{lcc}
\hline Blood Group & No & $\%$ \\
\hline A & 8077 & 25.28 \\
B & 10434 & 32.66 \\
O & 10705 & 33.51 \\
AB & 2725 & 8.53 \\
\hline Total & 31941 & $100 \%$ \\
\hline
\end{tabular}

Table-II

Frequency of Rh D blood group ( $n=31941)$

\begin{tabular}{lcc}
\hline $\begin{array}{l}\text { Rh D blood } \\
\text { group }\end{array}$ & No & $\%$ \\
\hline Rh D positive & 30809 & 96.41 \\
Rh D negative & 1132 & 3.54 \\
\hline Total & 31941 & $100 \%$ \\
\hline
\end{tabular}


Table III

Frequency of $A B O$ group and $R h D$ type $(n=31941)$

\begin{tabular}{lcccc}
\hline ABO group & No of Rh D positive & $\%$ & No of Rh D negetive & $\%$ \\
\hline A & 7811 & 24.45 & 266 & .83 \\
B & 10067 & 31.52 & 367 & 1.15 \\
O & 10307 & 32.27 & 398 & 1.25 \\
AB & 2624 & 8.21 & 101 & .32 \\
Total & 30809 & $96.41 \%$ & 1132 & $3.54 \%$ \\
\hline
\end{tabular}

Table IV

Frequency of $A B O$ and $R h D^{20,21,22,23}$

\begin{tabular}{lcccccccc}
\hline Country & $\mathrm{A}+$ & $\mathrm{A}-$ & $\mathrm{B}+$ & $\mathrm{B}-$ & $\mathrm{O}+$ & $\mathrm{O}-$ & $\mathrm{AB}+$ & $\mathrm{AB}-$ \\
\hline India & $22.1 \%$ & $0.08 \%$ & $30.9 \%$ & $1 . .1 \%$ & $36.5 \%$ & $2.0 \%$ & $6.4 \%$ & $0.2 \%$ \\
Australia & $31 \%$ & $7 \%$ & $8 \%$ & $2 \%$ & $40 \%$ & $9 \%$ & $2 \%$ & $1 \%$ \\
UK & $35 \%$ & $7 \%$ & $8 \%$ & $2 \%$ & $37 \%$ & $7 \%$ & $3 \%$ & $1 \%$ \\
USA & $35.7 \%$ & $6.3 \%$ & $8.5 \%$ & $1.5 \%$ & $37.4 \%$ & $6.6 \%$ & $3.4 \%$ & $0.6 \% \mathrm{~B}$ \\
\hline
\end{tabular}

\section{Discussion:}

In this study, among 31914, blood group A were 8077 (25.24\%), B were 10434 (32.66\%), O were 10705 (33.51\%) and $\mathrm{AB}$ were 2725 (8.33\%).In Bangladesh, group A were $22.44 \%$, B were $35.20 \%$, O were $33.97 \%$ and $A B$ were $8.39 \%{ }^{13}$. In India group A were $22 \%$, B 33\%, O 37\%, AB $7 \%$. In Japan, group A 38\%, B 22\%, O 30\% AB $10 \%$. In Asia group A 28\%, B 27\%, O 40\%, AB $5 \%{ }^{14}$. Blood group $\mathrm{B}$ has highest frequency in central Asia. It is believed that it is entirely absent from native American and Australian aboriginal populations ${ }^{15}$. Blood group $B$ is higher in Europe (25-55\%), highest in Australian aboriginal populations $(45 \%)^{16}$. In this study, Rh D negative were 1132 (3.54\%) and Rh D positive were $30809(96.41 \%)$. In Europe, Rh D negetive $35 \%$ and $\mathrm{Rh} \mathrm{D}$ positive $65 \%$. In America $\mathrm{Rh} \mathrm{D}$ negative $7 \%$ and $\mathrm{Rh} \mathrm{D}$ positive 93\%. In Asia Rh D negative less than 1\% and $\mathrm{Rh} \mathrm{D}$ positive $99 \%{ }^{17}$. Rh negative blood types are much less in portion of Asian population $(1 \%)$ than in white $(15 \%)^{18}$. In Bangladesh, Rh D negative $2.56 \%$ and Rh D positive $96.44 \%{ }^{19}$. In this study, blood group A+7411(24.45\%), A$266(0.83 \%), \mathrm{B}+10067(31.52 \%), \mathrm{B}-367(1.15 \%)$, $\mathrm{O}+10307(32.27 \%), \mathrm{O}-394(1.25 \%), \mathrm{AB}+$ 2624(8.21\%), AB- 101(0.32\%).

\section{Conclusion:}

This study will be helpful to the physicians and gynecologist to identify those patients who are at risk of mismatched transfusion and haemolytic disease of newborn.

\section{Acknowledgement:}

Special thanks to all medical and non-medical persons of the Department of Transfusion Medicine, DMCH, Dhaka, for their service and cordial help for the study.

\section{References:}

1. Makroo RN. Compendium of transfusion medicine. $1^{\text {st }}$ ed. New Delhi: J. Mitra \& Co; p. 20.

2. Landsteiner K, Weiner AS. An agglutinable factor in human blood recognized by immune sera for Rh blood. Proc Soc Exp Bid Med 1940; 43: 223-4.

3. Maton A. Human Biology and Health. $3^{\text {rd }}$ ed. New Jersy: Prentice Hall; 1997.

4. Table of blood group system. International Society of Blood Transfusion. October 2008, Retrieved 2008-09-12.

5. American Red Cross Blood Services, New England Region 2001, Archived from the original, June 21, 2004. Retrieved 2008-7-15.

6. Slayboldt C, Rearden A, Lane TA. B Antigen acquired by normal A1 red cells exposed to a patient serum. Transfusion 1987; 27(1): 41-4. 
7. Dean L. The ABO blood group: Blood group and red cell antigens- A number of illness may alter a person's ABO phenoype.

8. Matsushita S, Imanura T, Mizuta T. Acquired B Antigen And Polyagglutination In A Patient With Gastric Cancer. Japanese J Surg 1983; 13(6): 540-2.

9. Chown B, Lewis M. A 'new' Kell blood group phenotype. Nature 1957; 180(4588): 711.

10. Millor LH, Manson ST, Clyde DF. The resistance factors to Plasmodium vivax in Blacks. New Engl J Med 1976; 295(6): 302-4.

11. Makroo RN, Compendium of transfusion medicine. New Delhi: Mitra \& Co; p.24-6.

12. Talaro KP. Foundation in microbiology. $5^{\text {th }}$ ed. New York: McGraw-Hill; 2005. P.510-1.

13. Rahman M. Guide to blood transfusion. $2^{\text {nd }}$ ed. 2010. p. 98-100.

14. Racial and Ethnic Distribution of ABO Blood Types. Blood book . com. Retrieved 2010-04-01.

15. Encyclopedia Britanica. The maximum frequency of B gene occur in Central Asia and Northern India. 2002.
16. Technical Monograph No: 2. The ABO blood group system and ABO Subgroup. Biotech: March 2005.

17. Mack S. The Rh negetive blood type more prevalent in certain ethnic group? Mad. Sci Network. (March $21,2001)$.

18. Rh frequency: Hospital Kingnet.com.tw. Retrieved 2010-04-01.s

19. Rahman M, Abdullah AZM, Nandy CK, Mollah AA. Rhesus genotype frequency in Bangladeshi population. Bangladesh Med Res Counc Bull 1992; 18(2): 89-92.

20. Indian Journal for the Practicing Doctors. Indmedica.com. Retrieved 2009-11-07.

21. Blood types - what are they? Australian Red Cross. giveblood.red cross.org.au. Archived from the original on July 19, 2008. Retrieved 2010-08-01.

22. Frequency of major blood groups in UK. Blood.com.uk. Retrieved 2010-08-01.

23. Blood types in USA. Blood centre. stanford. edu. 2008-06-20. Retrieved 2010-08-01. 